\title{
Deficiency of Either P-Glycoprotein or Breast Cancer Resistance Protein Protect Against Acute Kidney Injury
}

\author{
Miriam Huls, * Joost P. H. Schoeber,* Catherine M. Verfaillie, $\dagger$ Aernout Luttun, \\ Fernando Ulloa-Montoya, $\dagger$ Aswin L. Menke, $\S$ Lars R. van Bolderen,,$[$ Rob M. Woestenenk, $\S$ \\ Gerard F. M. Merkx,\# Jack F. M. Wetzels, ** Frans G. M. Russel,* and Rosalinde Masereeuw*
*Department of Pharmacology and Toxicology, Radboud University Nijmegen Medical Centre, Nijmegen, The Netherlands
$†$ Interdepartmental Stem Cell Institute, Katholieke Universiteit Leuven, Leuven, Belgium
$\$$ Centre for Molecular and Vascular Biology, Katholieke Universiteit Leuven, Leuven, Belgium
$\S$ Central Hematology Laboratory, Radboud University Nijmegen Medical Centre, Nijmegen, The Netherlands
ID Department of Radiation Oncology, Radboud University Nijmegen Medical Centre, Nijmegen, The Netherlands \#Department of Human Genetics, Radboud University Nijmegen Medical Centre, Nijmegen, The Netherlands
**Department of Nephrology, Radboud University Nijmegen Medical Centre, Nijmegen, The Netherlands

\begin{abstract}
The kidney has a high capacity to regenerate after ischemic injury via several mechanisms, one of which involves bone marrow-derived (stem) cells. The ATP binding cassette transporters, P-glycoprotein and breast cancer resistance protein, are determinants for the enriched stem and progenitor cell fraction in bone marrow. Because they are upregulated after acute kidney injury, we hypothesized that both efflux pumps may play a role in protecting against renal injury. Surprisingly, transporter-deficient mice were protected against ischemia-induced renal injury. To further study this, bone marrow from irradiated wild-type mice was reconstituted by bone marrow from wild-type, P-glycoprotein- or breast cancer resistance protein-deficient mice. Four weeks later, kidney injury was induced and its function evaluated. Significantly more bone marrow-derived cells were detected in kidneys grafted with transporter-deficient bone marrow. A gender mismatch study suggested that cell fusion of resident tubular cells with bone marrow cells was unlikely. Renal function analyses indicated an absence of renal damage following ischemia-reperfusion in animals transplanted with transporter-deficient bone marrow. When wild-type bone marrow was transplanted in breast cancer resistance protein-deficient mice this protection is lost. Furthermore, we demonstrate that transporter-deficient bone marrow contained significantly more monocytes, granulocytes, and early outgrowth endothelial progenitor cells.
\end{abstract}

Key words: Bone marrow transplantation; Ischemia-reperfusion injury; Renal function; Side population; $\mathrm{ABC}$ transporter

\section{INTRODUCTION}

Acute kidney injury (AKI) is a frequent clinical problem with a high mortality, affecting many patients, particularly in the intensive care unit. Nevertheless, the proximal tubular epithelium, mostly affected after injury, has a high capacity to regenerate. Surviving tubular cells can proliferate and spread to the place of injury to repair the damaged epithelium. In addition, resident tubular cells may dedifferentiate into a more primitive mesenchymal phenotype, thought to serve as resident stem cells in the kidney, and repair the damage via a process called epithelial-to-mesenchymal transition (EMT)
$(2,11)$. However, EMT may also lead to renal fibrosis (13), eventually compromising renal function. Finally, bone marrow (BM) cells may play a role in renal regeneration. Within the BM, several stem cell populations with pluripotent characteristics, viz. the multipotent adult progenitor cells (MAPC), the hematopoietic stem cell population (HSC), the ckit ${ }^{+}, \mathrm{Sca}^{-1}{ }^{+}, \mathrm{lin}^{-}(\mathrm{KSL}) \mathrm{sub}-$ population, and mesenchymal stem cells (MSC), may aid in renal regeneration $(17,29,35,37,38,40)$. A key feature of these stem cells, and especially of the side population (SP) comprising $73 \%$ of the KSL subpopulation in HSC (5), is their expression of two efflux pumps, $\mathrm{P}$-glycoprotein (P-gp), the multidrug resistance gene 1

Received August 29, 2009; final acceptance April 20, 2010. Online prepub date: May 4, 2010

Address correspondence to Rosalinde Masereeuw, Ph.D., Department of Pharmacology and Toxicology (149), Radboud University Nijmegen Medical Centre, Nijmegen Centre for Molecular Life Sciences, P.O. Box 9101, 6500 HB Nijmegen, The Netherlands. Tel: +31 243613730; Fax: +31 243614214; E-mail: R.Masereeuw@pharmtox.umcn.nl 
$(M D R 1)$ product, and breast cancer resistance protein 1 (BCRP).

$\mathrm{P}-\mathrm{gp} / A B C B 1$ and $\mathrm{BCRP} / A B C G 2$ belong to the superfamily of ATP binding cassette (ABC) transporters and are expressed mainly in excretory organs, such as the liver, intestine, and the kidney. Localization studies revealed that within the kidney both efflux pumps are expressed at the apical membrane of renal proximal tubule cells $(20,46)$. ABC transporters protect against accumulation of xenobiotics and other potentially toxic substances. Moreover, BCRP protects progenitor cells under hypoxic conditions by reducing the accumulation of detrimental products like heme and porphyrin (32). Both transporters have been implicated in tissue regeneration, as P-gp expression is increased in severe human liver disease (43) and expression of BCRP increases following stroke (8). In the kidney, differential expression of $\mathrm{P}$-gp and BCRP is detected during pathological circumstances. Cadmium- and endotoxin-mediated renal damage is associated with elevated levels of P-gp $(19,45)$, and P-gp and BCRP expression increase after ischemic renal injury in mice (24).

P-gp and BCRP may regulate hematopoietic development. When constitutively expressed, BCRP stimulates the growth potential of human (hematopoietic) clonogenic progenitor cells (1). On the other hand, expression of human BCRP in murine BM cells increased the SP population and blocked maturation (52), whereas enforced expression of P-gp in murine HSC resulted in a marked expansion of repopulating cells and a myeloproliferative disease (6). Loss of expression of P-gp in murine $\mathrm{BM}$ resulted in an increased SP fraction, possibly due to compensatory upregulation of BCRP. However, loss of the $a b c g 2$ gene led to a reduction in the number of SP cells (51).

We hypothesized that if BM-derived cells aid in renal repair following ischemia-reperfusion, and if $\mathrm{P}$-gp and BCRP play a role in renal repair, deficiency of P-gp or $\mathrm{BCRP}$ in BM cells will lead to a decreased recovery in renal function following ischemia-reperfusion. To investigate this, BM from irradiated wild-type (WT) mice was reconstituted by transplanting BM from WT, P-gp-deficient, or BCRP-deficient mice. Four weeks later, kidney injury was induced and after 7 days its function was assessed, and, subsequently, kidneys were evaluated for the number and phenotype of BM-derived cells present. Surprisingly, we found that P-gp or BCRP deficiency in $\mathrm{BM}$ resulted in improved renal outcome following ischemia-reperfusion injury.

\section{MATERIALS AND METHODS}

\section{Animals}

The animal ethics board of the Radboud University Nijmegen Medical Centre approved all experimental procedures. Male, WT, Friend leukemia virus B strain mice (FVB) (6-8 weeks) were obtained from Charles River (Germany), and were housed under routine laboratory conditions at the Central Animal Facility Nijmegen. P-gp-deficient ( $\left.m d r l a / 1 b^{-/}\right)$or BCRP-deficient $\left(\right.$bcrp $\left.^{-/-}\right)$ mice (6-8 weeks; FVB background) were bred and housed in Nijmegen. For the collection of blood and urine, mice were individually housed in metabolic cages (Techniplast, Exton, USA) as described previously (20,21). Mice were allowed to adapt to these cages for 1 day, and after a rest period of 1 day, 24-h urine samples were collected. Mice were injected intraperitoneally $0.5 \mathrm{ml}$ of $0.9 \% \mathrm{NaCl}$ (B. Braun Melsungen AG, Melsungen, Germany) in order to maintain a normal fluid balance. Food and water were available ad libitum. AKI was applied by bilateral clamping in BCRP-deficient mice as described previously (21). In transplantation studies we applied unilateral ischemic renal injury by clamping the left renal artery and vein for $30 \mathrm{~min}, 4$ weeks after transplantation of BM cells. The bilateral clamping is most effective; however, inducing bilateral ischemic injury in transplanted FVB mice is near-tofully lethal, as these mice are also recovering from irradiation that induces renal injury (39). Blood and urine were used for standard clinical chemistry analyses; serum and urine creatinine levels were measured by HPLC (12). The fractional excretion of sodium was calculated according to the following equation: $\mathrm{FE}_{\mathrm{Na}}=100 \times$ $\left(\mathrm{Na}_{\text {urine }} \times\right.$ creatinine $\left._{\text {plasma }}\right) / \mathrm{Na}_{\text {plasma }} \times$ creatinine $\left.{ }_{\text {urine }}\right)$.

To characterize proximal tubular function we injected 16 mice subcutaneously with $10 \mathrm{mmol} / \mathrm{kg}$ body weight of lithium chloride (Merck, Darmstadt, Germany). After collecting blood from all mice before injection, mice were divided in groups of four and blood was collected 1, 3, 6, and $8 \mathrm{~h}$ after injection. Lithium concentrations were determined in serum according to the method described by Tabata et al. (44).

\section{Transduction of Primary Mouse BM Cells}

Chemicals and cytokines were obtained from Sigma (Zwijndrecht, The Netherlands), unless stated otherwise. $\mathrm{BM}$ was harvested from the femurs, and cells were cultured at $37^{\circ} \mathrm{C}, 5 \% \mathrm{CO}_{2}$ for 2 days in IMDM medium (Invitrogen, Life Technologies, Breda, The Netherlands) supplemented with $10 \%$ fetal calf serum (Integro, Zaandam, The Netherlands), $1 \%$ penicillin (5000 U) and streptomycin $(5 \mathrm{mg} / \mathrm{ml})$ solution (Invitrogen), $7 \mu \mathrm{l} / \mathrm{L}$ $\beta$-mercaptoethanol, $1 \%$ bovine serum albumin, $1 \% \mathrm{nu}-$ cleoside mix $(0.1 \mathrm{mg} / \mathrm{ml}$ cytidine, adenosine, uridine, guanosine, 2'-deoxycytidin, 2'-deoxyadenosine, thymidine, $2^{\prime}$-deoxyguanosine), $10 \mu \mathrm{g} / \mathrm{ml}$ bovine insulin (Invitrogen), $15 \mu \mathrm{M}$ cholesterol, $15 \mu \mathrm{M}$ linolic acid, 0.62 $\mathrm{mg} / \mathrm{ml}$ human transferring, and the following recombinant cytokines: murine stem cell factor $50 \mathrm{ng} / \mathrm{ml}$, murine 
interleukin (IL)-12 $10 \mathrm{ng} / \mathrm{ml}$, murine IL-3 $10 \mathrm{ng} / \mathrm{ml}$, human FMS-like tyrosine kinase 3 (Flt-3) $50 \mathrm{ng} / \mathrm{ml}$, human thrombopoeitin $10 \mathrm{ng} / \mathrm{ml}$ (ITK Diagnostics, Uithoorn, The Netherlands), anti-TGF- $\beta 1 \mu \mathrm{g} / \mathrm{ml}$ (ITK Diagnostics). Cells were plated onto retronectin-coated culture dishes (Takara, Cambrex Bio Science, Heerhugowaard, The Netherlands) and exposed to the supernatant of packaging, ecotropic Phoenix cells, transfected with retroviral vector pLZRS encoding for enhanced green fluorescent protein (eGFP) $(16,18)$. Twenty-four hours after exposure to the retroviral vector, cells were collected and eGFP-positive cells selected using an Epics Altra flow cytometer (Beckman Coulter, Miami, FL, USA).

\section{Irradiation and Transplantation}

Mice were irradiated with a single dose of $3.5 \mathrm{~Gy}$ (6 MV) using a Digital Precise SLi Linear Accelerator (Elekta, Crawley, UK) and subsequently $10^{6}$ eGFP-positive BM cells, diluted in $100 \mu 10.9 \% \mathrm{NaCl}$ (B. Braun Melsungen AG) were injected via the tail vein. After transplantation, mice were housed under semisterile conditions to avoid infections. The amount of eGFP-positive cells in the circulation was measured by fluorescence-activated cell sorting (FACS) $24 \mathrm{~h}$ after induction of ischemia-reperfusion injury. After collecting blood from the retro-orbital sinus, erythrocytes were lysed and the amount of eGFP-positive cells in the peripheral blood was determined.

\section{Histology and Semiquantification of Morphometric Analysis}

For light microscopy, kidney fragments were fixed in Bouin's solution, dehydrated, and embedded in paraplast (Amstelstad, Amsterdam, The Netherlands); sections of $3 \mu \mathrm{m}$ were stained with periodic acid-Schiff. The renal sections were examined for abnormalities and the number of pycnotic nuclei was semiquantitatively calculated. Nuclear alteration, such as pycnosis, generally is considered a reflection of reduced vital cellular functions. Images of $768 \times 573$ pixels were analyzed and the number of condensed nuclei of cells undergoing apoptosis was counted for each image.

\section{Immunohistochemistry and Quantification of Renal Tubules From Donor Origin}

For immunohistochemistry, kidney fragments were snap frozen in liquid nitrogen and $2-\mu \mathrm{m}$ cryostat sections were used. Sections were fixed in acetone for 10 min and air dried. Slices were incubated with primary antibodies against GFP (diluted 1:200, Roche Diagnostics, Basel, Switzerland), Ter-119/Ly-76 (diluted 1:200), MAC-1 (diluted 1:200, Becton Dickinson, Breda, The Netherlands), BCRP (diluted 1:50; BXP-9, Kamiya Biomedical Systems, Seattle, WA, USA), or P-gp (diluted
1:100; C219, Dako Diagnostics BV, Herverlee, Belgium) in PBS, $0.5 \%$ BSA for $1 \mathrm{~h}$ at room temperature. Next, slices were washed three times with PBS and incubated with the secondary antibody: goat anti-mouse Alexa Fluo 488 was used for GFP, goat anti-rabbit Alexa Fluo 594 for Ter-199/Ly-76 and P-gp, and goat anti-rat Alexa Fluo 594 for BCRP, all diluted 1:200 in $\mathrm{PBS} / 0.5 \%$ BSA. Sections were examined using a confocal laser-scanning microscope (CLSM; Leica lasertechnik $\mathrm{GmbH}$, Heidelberg, Germany). Renal tubule cells that originated from transduced BM cells were calculated 7 days after the injury by staining with antibodies directed against GFP and applying confocal microscopy. For semiquantification, a single green cell in the kidney cortex counted for a positive tubule. Data are expressed as percent of total number of tubules.

\section{Fluorescence In Situ Hybridization}

Fluorescence in situ hybridization was performed using a mouse whole chromosome $\mathrm{X}$ [fluorescein-isothiocyanate (FITC) labeled; green) and Y [cyanine-3 (Cy3) labeled; red] painting (Cambio, Cambridge, UK) according to de Bruijn et al. (9). In brief, 4- $\mu \mathrm{m}$-thick sections of perfused frozen mouse kidney from WT-WT gender mismatch transplantations were pretreated with pepsine (Sigma), prefixed in $70 \%$ ethanol at $-20^{\circ} \mathrm{C}$, washed with Nonidet P40 (Fluka, Sigma-Aldrich, Buchs, Switzerland), and dehydrated. An amount of $3 \mu \mathrm{l}$ of each chromosome paint was used in a total of $10 \mu \mathrm{l}$ hybridization mix (Cambio) and administered under a coverslip of $20 \times 20 \mathrm{~mm}$ and denatured simultaneously on a Hybaid Omnislide (Thermo Electron, Milford, MA, USA). Posthybridization was performed by a wash step of $0.4 \mathrm{SSC} /$ Tween- 20 at $68.5^{\circ} \mathrm{C}$ followed by several steps of $2 \times$ SSC, $4 \times$ SSC, and PBS at room temperature. After dehydration slides were counterstained with DAPI (Vector) and eGFP, and 100 eGFP-positive cells were analyzed. A Zeiss Axiophot-2 microscope (Zeiss, Germany) equipped with appropriate fluorescence filters was used for qualitative analysis of the fluorescence signals. The specimen was scanned for clearly recognizable individual cells to facilitate reliable scoring of the chromosome paintings. Images were captured by a Leica DC 350FX camera using Leica CW4000 software package (Leica, Germany).

\section{Western Blot Analysis}

Total renal fractions of six pooled kidneys were obtained using the micro-dismembrator (Sartorius BBI Systems GmbH, Melsungen, Germany). To this end, perfused frozen kidneys were pulverized $(2000 \mathrm{rpm}, 30$ s) and transferred to ice-cold TS buffer (10 mM Tris$\mathrm{HCl}, 250 \mathrm{mM}$ sucrose) containing protease inhibitors (1 $\mathrm{mM}$ phenylmethylsulfonyl fluoride, $1 \mu \mathrm{g} / \mathrm{ml}$ aprotinin, 5 
$\mu \mathrm{g} / \mathrm{ml}$ leupeptin, $1 \mu \mathrm{g} / \mathrm{ml}$ pepstatin, and $10 \mu \mathrm{M}$ E64). These suspensions were centrifuged for $12,000 \times g, 30$ $\min , 4^{\circ} \mathrm{C}$ and the resulting supernatant contained the total fraction. From these fractions, $50 \mu \mathrm{g}$ was solubilized in Laemmli sample buffer, heated at $65^{\circ} \mathrm{C}$ for $10 \mathrm{~min}$, separated on a $10 \%$ sodium dodecyl sulfate (SDS)-polyacrylamide gel, and transferred to Hybond-C pure nitrocellulose membrane. Analysis was performed by the Odyssey infrared imaging system (LI-COR, Biosciences, NE, USA). The membrane was blocked in Odyssey blocking buffer diluted 1:1 with PBS for $1 \mathrm{~h}$ at room temperature. Subsequently, the membrane was incubated overnight with the primary antibodies at $4^{\circ} \mathrm{C}$ : GFP (1: 200; Invitrogen, Breda, The Netherlands) and $\beta$-actin (1: 100,000; Sigma, Zwijndrecht, The Netherlands) diluted in PBS supplemented with $0.1 \%$ Tween-20 and $0.01 \%$ SDS. After three washing steps of $10 \mathrm{~min}$ in PBS, the blot was incubated in the dark at room temperature for 60 min with the secondary antibody in PBS $0.1 \%$ Tween-20; IRDye 800 anti-rat and IR-Dye 800 antimouse (Rockland Immunohistochemistry Inc., Gilbertsville, USA). After repeating the washing steps images were acquired with the Odyssey infrared imaging system and analyzed by the software program as specified in the Odyssey software manual. For semiquantification, we measured the pixel intensity of the bands using Scion image version beta 4.02 for Windows (Scion Corp., Frederick, MD, USA).

\section{BM and Early Endothelial Progenitor Cell Characterization}

BM cells were isolated as described above and erythrocytes were lysed. After centrifugation, BM was washed and fractions were stained with the following conjugated antibodies: Sca-1, c-kit, Thy1.1, Ter 119, CD45.1, CD45.2, Mac-1, Gr-1, CD4, CD8, CD19, B220, CD31, CD34, and isotype controls (BD Biosciences, Alphen a/d Rijn, The Netherlands). Thereafter, $\mathrm{BM}$ cells were analyzed using FACS to determine cell surface phenotype. Early outgrowth endothelial progenitor cells (EPCs) were isolated from spleens of adult mice (six per genotype) and cultured according to Yoder et al. (50). Early endothelial outgrowth was scored by incubating the cells with DiI-acetylated low density lipoprotein (AcLDL; Biomedical Technical Inc., Stoughton, USA), staining with FITC-Bandeiraea Simplicifolia (BS)-I lectin (Sigma, Belgium), and counting the number of double positive cells for each well. Results were expressed as the average number of double positive cells per area (in $\left.\mathrm{cm}^{2}\right)$.

\section{Data Analysis}

Data are presented as means \pm SEM. Mean values were considered to be significant when $p<0.05$ by use of a one-way ANOVA followed by Bonferroni's multiple comparison test. Software used for statistical analysis was Graphpad Prism ${ }^{\circledR}$ (version 4.03 for Windows; Graphpad Software, San Diego, CA, USA).

\section{RESULTS}

\section{BCRP-Deficient Mice Are Protected Against Ischemic Renal Injury}

Renal function in BCRP-deficient animals was evaluated following an ischemic insult of bilateral clamping of the renal arteries and veins for $30 \mathrm{~min}$. Wild-type animals followed a typical pattern of reversible renal damage (24), characterized by a decrease in creatinine clearance 2 days after ischemia and restoration to near normal levels by day 7 . In contrast, creatinine clearance increased in BCRP-deficient mice during the 7 days after ischemia (Fig. 1A). These findings were confirmed by renal histology (Fig. 1B, C), where signs of tubular damage (pycnotic nuclei, cell blebbing, brush border loss), apparent 2 days after injury, in WT mice were not present in kidneys from BCRP-deficient animals. In addition, renal functional parameters were determined (summarized in Table 1) and demonstrated increased urine flow and slightly elevated creatinine and inulin clearances (defining the glomerular filtration rate, GFR) in these knockout mice. Importantly, the BCRP-deficient mice show normal proximal tubular function as determined by the fractional excretion of sodium and lithium clearance.

\section{Deficiency of P-gp or BCRP in BM-Derived But Not in Resident Cells Protects Against Ischemic Injury}

To investigate whether the protection against AKI observed in P-gp- and BCRP-deficient mice is a result of the transporter deficiency in BM, we first set up an experimental model of BM engraftment in AKI (23). eGFP-transduced BM cells derived from WT, BCRPdeficient, or P-gp-deficient mice were transplanted into WT mice. Four weeks later, unilateral ischemia was induced and renal function was evaluated at different time points thereafter. Wild-type mice grafted with WT BM (WT-WT) showed decreased creatinine clearance 2 days after ischemia (Fig. 2A), which returned to near normal levels on day 7 , consistent with nontransplanted mice (Fig. 1A). In contrast, animals transplanted with P-gpdeficient BM (P-gp-WT) had increased creatinine clearances 2 days after injury $(p<0.05)$, which returned to baseline after 7 days (Fig. 2A). Animals transplanted with BCRP-deficient BM (BCRP-WT) showed a comparable increase in creatinine clearance $(p<0.05)$, but this remained elevated after 7 days (Fig. 2A), similar to BCRP-deficient mice (Fig. 1A). Furthermore, fractional excretion of sodium $\left(\mathrm{FE}_{\mathrm{Na}}\right)$ was calculated to determine renal tubular function. Two days after ischemia, solely 

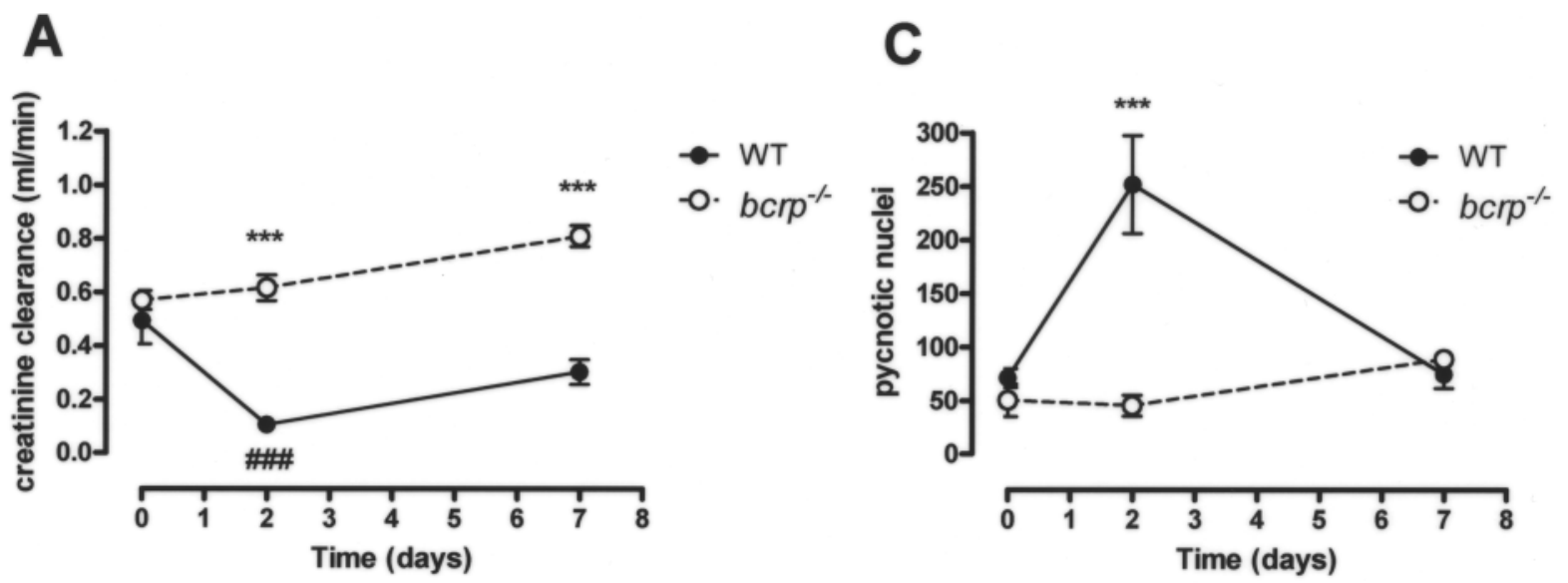

B

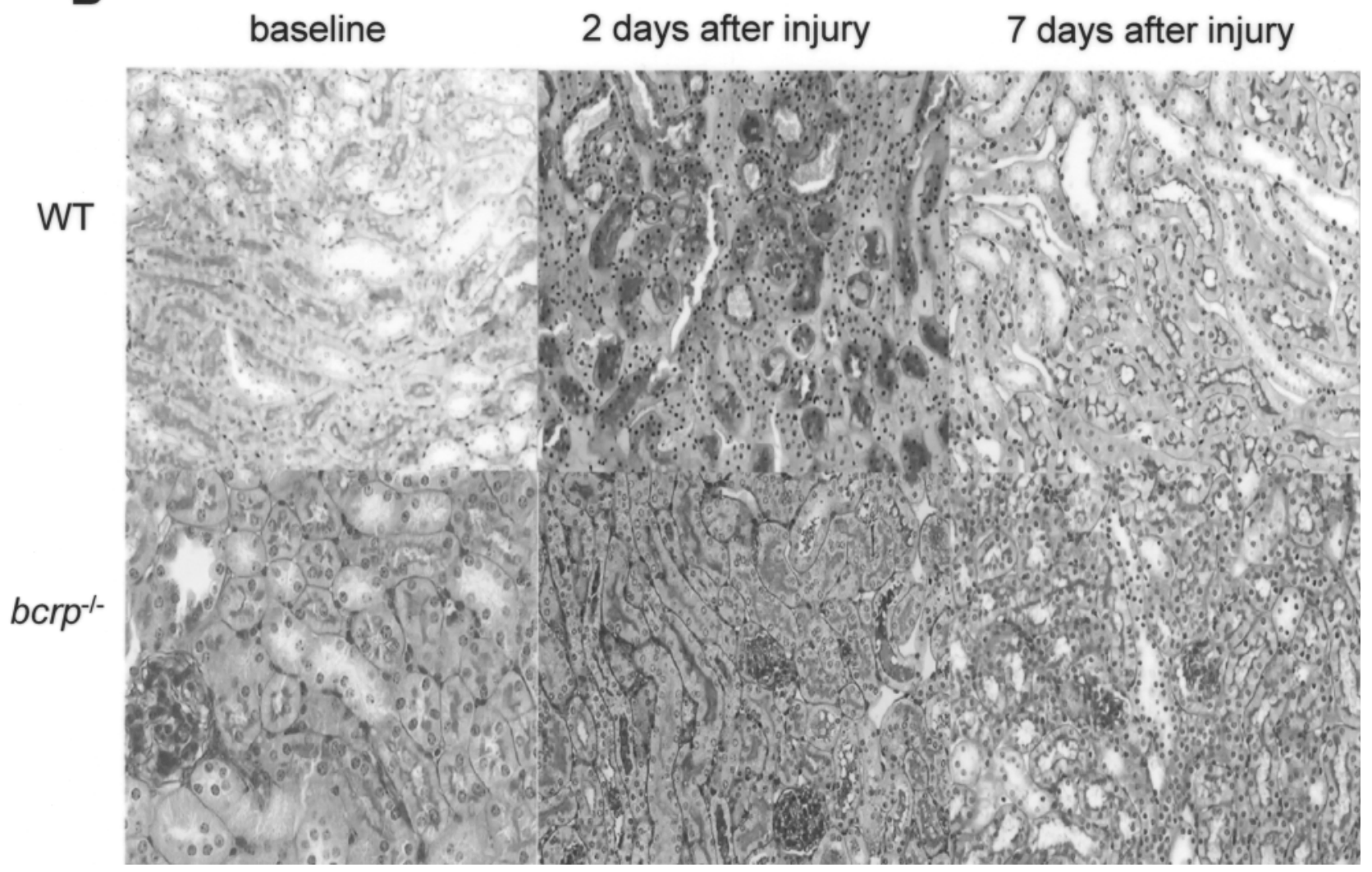

Figure 1. BCRP-deficient mice are resistant to renal ischemia. AKI was applied by bilateral clamping of renal arteries and veins for $30 \mathrm{~min}$. (A) Renal function, measured as creatinine clearance in BCRP-deficient mice (open circles) compared to wild-type (WT) animals (filled circles), at baseline (0), 2, and 7 days after ischemia. Data are expressed as mean \pm SEM of six mice. ***p $<$ 0.001 compared to WT; \#\#\#p < 0.001 compared to baseline WT. (B) Representative histological images in WT and BCRP-deficient $\left(\mathrm{bcrp}^{--}\right)$mice at baseline (0), 2, and 7 days after ischemia. Pronounced renal tubular epithelial cell detachment from the basement membrane (cell debris) into the tubular lumen was observed in WT mice, whereas such an effect was absent in BCRP-deficient mice. Original magnifications: $\times 200, \times 400$. (C) For semiquantification, the number of pycnotic nuclei was calculated. Data are expressed as mean \pm SEM of 3-7 kidneys ( $b c r p^{-/}$baseline: $n=3$; WT baseline: $n=4$; $b c r p^{-/}$day $2: n=3$; WT day $2: n=4 ; b c r p^{-/}$ day 7: $n=4$; and WT day 7: $n=7)$. ***p $<0.001$ compared to BCRP-deficient animals. 
Table 1. Renal Characteristics of BCRP-Deficient Mice Compared to WT Mice

\begin{tabular}{|c|c|c|}
\hline & $\mathrm{WT}(n)$ & $\begin{array}{c}\text { BCRP } \\
\text { Deficient }(n)\end{array}$ \\
\hline Urine volume $(\mathrm{ml} / 24 \mathrm{~h})$ & $0.75 \pm 0.03(42)$ & $3.4 \pm 1.1 *(41)$ \\
\hline $\begin{array}{l}\text { Creatinine clearance } \\
\qquad(\mu \mathrm{l} / \mathrm{min})\end{array}$ & $493 \pm 107(5)$ & $569 \pm 35 \dagger(6)$ \\
\hline $\operatorname{GFR}(\mu 1 / \min )$ & $405 \pm 29(4)$ & $700 \pm 200 *(4)$ \\
\hline $\mathrm{FE}_{\text {sodium }}(\%)$ & $0.093 \pm 0.008$ & $0.095 \pm 0.017(6)$ \\
\hline $\begin{array}{l}\text { Lithium clearance } \\
\qquad(\mu 1 / \mathrm{min})\end{array}$ & $104 \pm 3(8)$ & $98 \pm 15(8)$ \\
\hline
\end{tabular}

Data are presented as mean values \pm SEM. WT, wild type; GFR, glomerular filtration rate determined by [methoxy- $\left.{ }^{3} \mathrm{H}\right]$ inulin clearance as

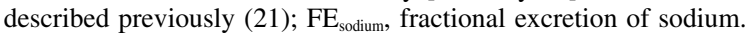
$* p<0.001$ compared to WT animals.

$\dagger p<0.05$ compared to WT animals.

the WT BM grafted animals had a significant increased $\mathrm{FE}_{\mathrm{Na}}$, despite the fact that they were within normal range, returning to baseline after 7 days. In line with the creatinine clearances the $\mathrm{FE}_{\mathrm{Na}}$ did not change in animals transplanted with P-gp-deficient or BCRP-deficient BM (Fig. 2A).

Histological analysis (Fig. 2B, C) confirmed the absence of renal damage following ischemia-reperfusion in WT animals transplanted with BM deficient of P-gp or BCRP. Animals grafted with WT BM showed significant damage with a loss of brush border membranes and obstruction of the tubular lumen on day 2. By day 7 , signs of recovery were observed. Kidneys of mice grafted with BCRP-deficient or P-gp-deficient BM showed intact brush border membranes and no tubular obstruction after injury.

To further substantiate the role of the ABC transporter $\mathrm{BCRP}$ on $\mathrm{BM}$-derived cells in renal regeneration, we transplanted eGFP-transduced WT BM in BCRPdeficient mice (WT-BCRP). Four weeks later, renal ischemia was established. Creatinine clearance and $\mathrm{FE}_{\mathrm{Na}}$ (Fig. 3A) were decreased on day 2 after the injury, but returned to baseline after 7 days without changing the renal phenotype (viz. urine flow still significantly in- creased as compared to WT-WT transplanted animals, $p<0.05$ ). This was confirmed by histology (Fig. 3B), because severe tubular alterations were observed comparable to WT mice transplanted with WT BM (Fig. 2B). These findings corroborate that absence of BCRP in BM cells, but not in resident cells, is beneficial for the kidney after injury.

\section{ABC Transporter-Deficient BM Engraftment Into WT Mice Results in Protection From AKI}

The level of engraftment of BM-derived cells in renal tubular cells in mice is small and varied, and literature values between $3 \%$ and $8 \%$ were reported $(14,40)$. We investigated the number of BM-derived cells present in the injured kidneys after transplantation of P-gp- or BCRP-deficient BM. To avoid false-positive results, confocal microscopy of eGFP staining with antibodies against GFP combined with other markers was applied. In WT BM grafted animals, few BM-derived cells were seen 2 days following the injury, but on day 7 BM cells were detectable throughout the kidney (Fig. 4A). In Pgp-deficient grafted animals, however, infiltration of eGFP-positive cells was already seen 2 days after ischemia and their number increased further after 7 days. To confirm the BM origin of infiltrating cells, tissues were counterstained with an antibody against P-gp, demonstrating that eGFP-positive cells did not express the ABC efflux pump (Fig. 4A). In BCRP-deficient BM grafted animals infiltration of eGFP-positive cells was even more pronounced (Fig. 4A, B). Western blot analysis supported the increased infiltration of eGFP-positive cells in BCRP-deficient or P-gp-deficient grafted animals (Fig. 4C). Infiltration of eGFP positive cells in the contralateral kidneys was negligible (data not shown).

Counterstaining with an erythrocyte marker clearly showed the localization of peritubular capillaries and glomeruli, which were not eGFP positive. We next quantified the amount of eGFP-positive tubules in WTWT, P-gp-WT, and BCRP-WT 7 days after the injury using confocal microscopy (Fig. 4B). Significantly more eGFP-positive cells were detected in kidneys of WT mice grafted with P-gp-deficient $(21.1 \pm 2.1 \% ; p<0.01)$

\section{FACING PAGE}

Figure 2. Kidneys of WT mice are protected against ischemia after transplantation of BM from P-gp- and BCRP-deficient mice. (A) Effects of renal ischemia reperfusion on creatinine clearance (left panel) and fractional excretion of sodium (right panel) in BCRP-WT (open circles), P-gp-WT (open squares), and WT-WT (filled circles) transplanted animals, 0, 2 , and 7 days after ischemia. Data are expressed as mean \pm SEM of $4-8$ mice. ${ }^{*} p<0.05$ compared to WT-WT; \#\#p $<0.01$, \#\#\#p $<0.001$ compared to baseline WT-WT. (B) Representative histological images confirm changes in renal function. G, glomerulus; PT, proximal tubules with cellular debris. Black arrows indicate brush border membranes (original agnifications: $\times 200, \times 400$ ). (C) For semiquantification, the number of pycnotic nuclei was calculated. Data are expressed as mean \pm SEM of $4-8$ kidneys (baseline: WT-WT, $n=4$; P-gpWT, $n=4$; BCRP-WT, $n=6$; day 2: WT-WT, $n=6$; P-gp-WT, $n=4$; BCRP-WT, $n=6$; day 7: WT-WT, $n=6$; P-gp-WT, $n=8$; BCRP-WT, $n=8)$. ${ }^{* *} p<0.01$ compared to BCRP-deficient animals. 

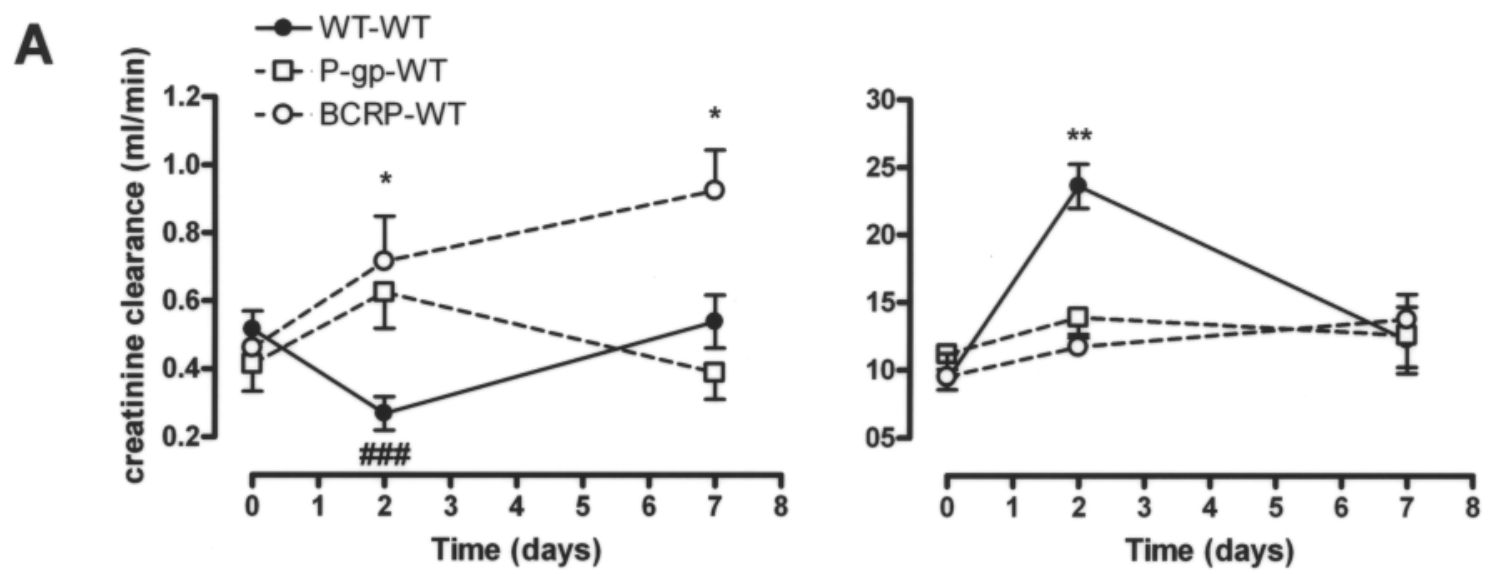

B
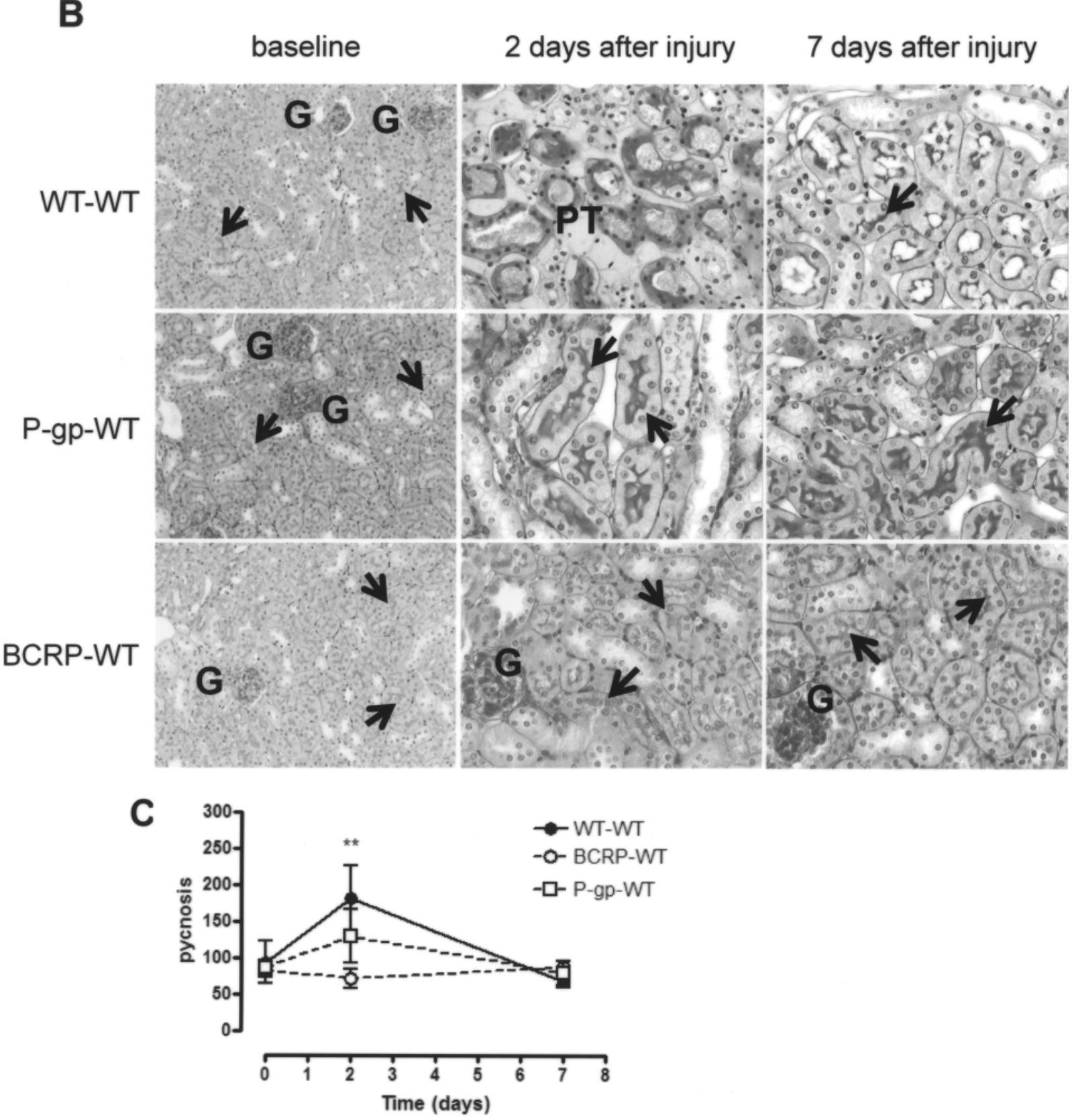

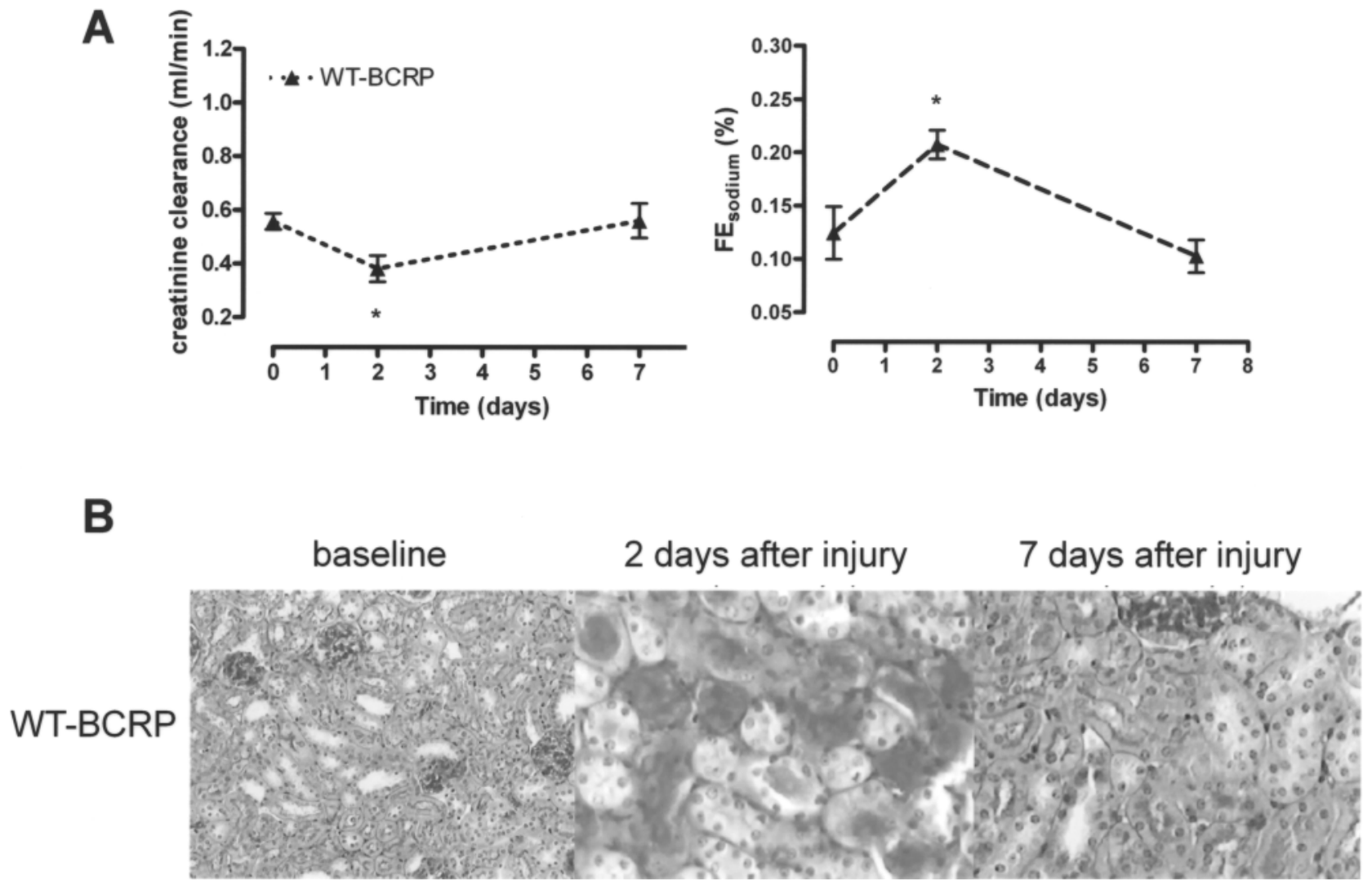

Figure 3. BCRP-deficient mice are not protected against renal AKI after transplantation with BM from WT mice. (A) Effects of renal ischemia reperfusion on creatinine clearance (left panel) and fractional excretion of sodium (right panel) in WT-BCRP transplanted animals, 0,2 , and 7 days after ischemia. Data are expressed as mean \pm SEM of 8 mice. $* p<0.05$ compared to baseline (Fig. 2A). (B) Representative histological images at baseline (0), 2, and 7 days after ischemia. Pronounced renal tubular epithelial cells detachment from the basement membrane (cell debris) into the tubular lumen was observed in BCRP-deficient mice transplanted with WT BM, comparable to the effect observed in WT-WT transplantations (Fig. 2B, upper panels) (original magnifications: $\times 200, \times 400)$.

or BCRP-deficient $(28.6 \pm 2.8 \% ; p<0.001)$ BM compared to WT transplantations $(9.6 \pm 2.1 \%)$.

\section{Possibility of Fusion of BM-Derived Cells With Resident Renal Tubular Cells}

Transdifferentiation of BM-derived cells may occur, at least in part, due to fusion between HSC-derived monocytes and target tissues. We performed gender mismatch transplantations with donor WT BM cells from female mice in sublethally irradiated WT male mice. After 4 weeks ischemia was induced by unilateral clamping. We found female donor cells engrafted in the tubules of the male kidney after AKI (Fig. 4D). The eGFP-positive cells were exclusively XX and we did not find any eGFP-positive cells containing a $\mathrm{Y}$ chromosome.
Increased Numbers of Mononuclear Cells and Early Outgrowth Endothelial Progenitor Cells in BM of P-gp- and BCRP-Deficient Mice

To understand how BM from P-gp- or BCRP-deficient mice may accelerate renal outcome, we investigated the BM composition of these mice by FACS analysis. A significantly increased proportion of monocytes $\left(\mathrm{CD}^{4} 5^{+}, \mathrm{MAC}-1^{+}\right)$and granulocytes $\left(\mathrm{CD}^{4} 5^{+}, \mathrm{Gr}-1\right)$ were present in both strains (Table 2), most pronounced in Pgp-deficient mice. In addition, the frequency of early outgrowth endothelial progenitor cells (EPCs), which were shown to be of monocytic origin (50), was determined after AcLDL uptake and BS-I lectin staining. We found higher frequencies in P-gp-deficient $(237 \pm 120$; $p=0.07)$ and BCRP-deficient $(110 \pm 28 ; p<0.05)$ mice than in WT mice (42 \pm 9$)$. Quantitative RT-PCR analy- 
sis of the EPCs demonstrated high expression levels of CD45, suggesting their hematopoietic origin, and similar levels of endothelial transcripts, indicating a numerical but not qualitative difference (not shown). These findings indicate that the increased amount of monocytes and granulocytes and the higher frequency of early outgrowth EPCs in BM of both knockout mice were involved in the protection against AKI, as observed in transplantation studies with this BM. An increased amount of MAC-1-positive cells observed in recipient kidneys transplanted with knockout BM compared to WT transplanted animals 7 days after renal injury further confirms increased monocyte infiltration (Fig. 4E). The KSL population in P-gp- and BCRP-deficient mice was comparable to WT mice (Table 2), suggesting that the SP population does not contribute to the protective effect.

\section{DISCUSSION}

In this study, we show that an absence of the efflux pumps, $\mathrm{P}$-gp or BCRP, on BM cells results in protection against renal ischemia-reperfusion injury. This effect cannot be explained by the function of these transporters in the kidney, because the knockout mice differ in renal physiology. Moreover, transplantation of BCRP-deficient mice with WT BM results in an attenuation of protection without changing kidney physiology. This is the first report describing such explicit role of P-gp and BCRP in renal protection by BM-derived cells.

Both $\mathrm{ABC}$ transporters have been implicated in multidrug resistance and tissue defense (22). BCRP is expressed in plasma membranes of different tissues with an important barrier function, such as the apical membrane of the small and large intestine, the canalicular membrane of hepatocytes, the mammary gland, the luminal membrane of the capillary endothelium of brain, and in the brush border membrane of the placenta (33). We recently identified the efflux pump in the apical membrane of human kidney proximal tubules as well (20), where BCRP likely contributes to the excretory processes of drugs and toxic substances in the urine. The present study shows that assessments of creatinine clearance and fractional sodium excretion after AKI point toward protection against ischemia-reperfusion injury, which is in agreement with our earlier findings for Pgp-deficient mice (21). These findings suggest that the functional absence of BCRP or P-gp attenuate renal injury. However, it is not likely that this is caused by alterations in renal function, because BCRP-deficient mice show no similarities with the renal functional phenotype of P-gp-deficient mice (21). The $b c r p^{-/}$mice show an increased urine flow and slightly elevated creatinine and GFR, which is in contrast to P-gp-deficient mice that show normal creatinine clearances but decreased GFR [see Table 1 and (21)]. Moreover, the BCRP-deficient mice have normal proximal tubular function. The observed hyperfiltration in BCRP-deficient mice compared to WT may be characterized as a compensatory response of remaining functional nephrons after the ischemic injury, helping to maintain renal function.

We further demonstrate that adoptive transfer of Pgp- or BCRP-deficient BM to WT kidneys by grafting mimics the observations in the transporter-deficient mice, and that adoptive transfer of WT BM in BCRPdeficient mice results in a loss of this protective effect. This remarkable protective phenomenon is likely due to enhanced BM engraftment in absence of P-gp or BCRP, although conflicting observations concerning the role of $\mathrm{BM}$ in renal tubular regeneration have been reported. Transdifferentiation of BM cells to functional tubular epithelium has been demonstrated previously $(14,29,31)$; however, beneficial effects of BM transplantations may have been accelerated by irradiation of mice prior to transplantation and kidney damage due to enhanced injury $(15,30)$. Others showed that BM cells may improve renal function without direct involvement in tubular epithelial engraftment (4). The observations in the latter study suggested that BM cells may predominantly contribute to the interstitial myofibroblast pool. In contrast, $\mathrm{BM}$ cells have also shown not to improve renal function despite their tubular engraftment (36).

The controversy in the literature may arise from variations in experimental models and various tracking methods used to characterize the BM-derived cell phenotype (e.g., transgenic reporter gene labeling of donor BM with GFP or Lac-Z and/or gender mismatch). Our gender mismatch studies confirmed engraftment of donor BM cells and, moreover, suggest that the mechanism of BM cell conversion into renal cells after AKI may not involve cell fusion between resident tubular cells and donor BM cells, although we cannot fully exclude the possibility of cell fusion. Our findings contradict with processes described for repopulation of other tissues, including liver, heart, and Purkinje neurons (3, 47,49); however, they are more in line with reports showing that fusion with resident renal tubular cells can occur but that it is a rare phenomenon $(14,34)$.

Enhanced GFP-tagged WT BM cells accounted for approximately $9 \%$ of postischemic kidney remodeling, which is in agreement with previous reports $(36,41)$. We performed our studies 4 weeks after BM transplantation and did not achieve full reconstitution of BM. Peripheral blood consisted of 55\% eGFP-positive donor BM cells (not shown), indicating that the remaining $45 \%$ is still from the recipient animal and that the observed contribution of BM to renal remodeling could be slightly un- 

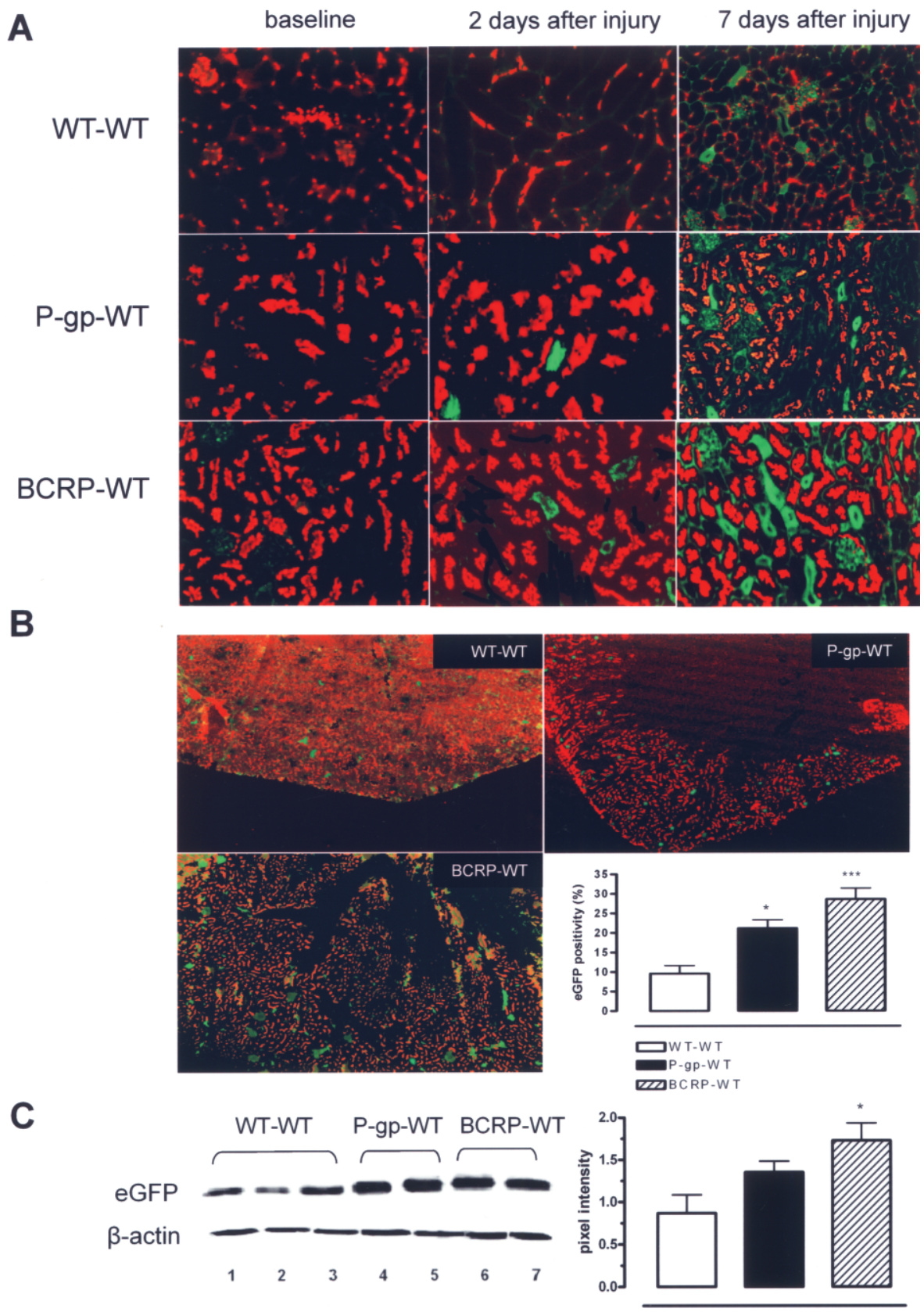

Figure 4. Enhanced infiltration of eGFP-labeled BM-derived cells in absence of P-gp or BCRP. (A) Representative kidneys from 6 WT-WT transplanted animals show eGFP-positive tubules (green) after 7 days. Staining was performed using an antibody against GFP (green). Counterstaining was performed with antibodies against Ter-119, an erythrocyte marker (red). Kidneys from 12 P-gpWT transplanted animals show infiltration of eGFP-labeled donor bone marrow cells after 2 days (representative for 6 mice), which further increased after 7 days (representative for 6 mice). Counterstaining of the GFP-positive tubules was performed with an antibody directed against P-gp (red), and indicates that cells were derived from P-gp-deficient BM. Staining of WT kidneys confirmed P-gp positivity (not shown). BCRP-WT transplanted animals $(n=6)$ also showed infiltration after 2 days, which increased after 7 days. Counterstaining (red) with an antibody directed against BCRP confirms the origin of the donor bone marrowderived cells (original magnification: $\times 200, \times 400$ ). (B) Overview of kidneys shown in (A) but with lower magnification, after WTWT, P-gp-WT, and WT-BCRP transplantations (original magnification $\times 100$ ). Quantification with confocal microscopy after staining with antibodies against GFP, in which one green cell accounted for a positive tubule, revealed the amount of eGFP-positive tubules expressed as percent of total number of tubules. ${ }^{*} p<0.05, * * * p<0.001$. (C) Representative Western blot of three independent blots loaded with four samples of each treatment confirms increased infiltration of BM-derived eGFP-labeled cells in transplanted animals 7 days after ischemia. Relative pixel intensities were determined through image analysis. Data are expressed as mean \pm SEM. $* p<0.05$. 

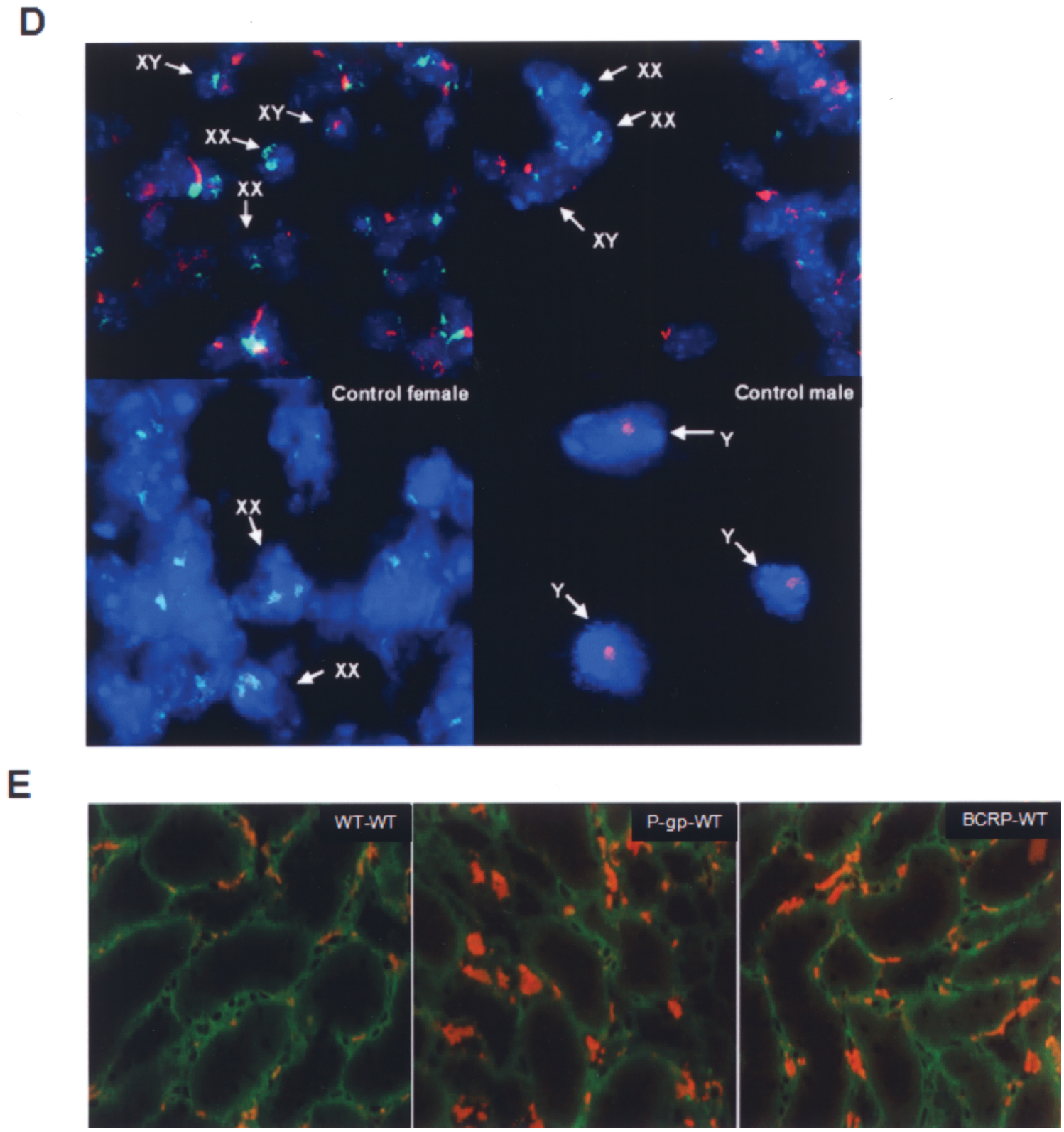

Figure 4. Continued. (D) BM-derived cells do not fuse with resident renal tubular cells. Female BM-derived cells in kidneys after transplantion of female WT mouse BM in four male WT recipients (indicated with arrows in upper panels). These cells show exclusively two X chromosomes (green) and no Y chromosome (red). Control images show the specificities of the X and Y chromosomal paints (original magnification: $\times 630$ ). (E) Increased amount of MAC-1-positive cells in recipient kidneys transplanted with knockout BM. MAC-1-positive cells (red) observed in P-gp-WT and BCRP-WT mice compared to WT-WT mice (original magnification: $\times 400)$.

derestimated. Still, the majority of epithelial repopulation originates from BM-independent processes. It was suggested that the most important mechanism of renal regeneration might occur through survival of dedifferentiated epithelial cells, which proliferate and redifferentiate into mature functional epithelial cells $(10,25)$. But this process may also hamper tissue remodeling by fibroblast formation, causing renal interstitial fibrosis (13).
Our analyses revealed that BM from P-gp or BCRP knockout mice contains significantly more myeloid cells (monocytes, granulocytes) and EPCs, which indicates that modulation of the immune response may be responsible for the regeneration rather than direct tubular differentiation. This is supported by recent literature on macrophage involvement in renal injury and repair $(27,42)$ and the findings that surviving tubular epithelial 
Table 2. BM Constitution in WT, P-gp-Deficient, and BCRP-Deficient Mice

\begin{tabular}{lccc}
\hline & \multicolumn{3}{c}{ P-gp } \\
& WT (\%) & $\begin{array}{c}\text { BCRP } \\
\text { Deficient (\%) }\end{array}$ & Deficient (\%) \\
\hline $\mathrm{Lin}^{-}, \mathrm{ckit}^{+}, \mathrm{Sca}^{+}$ & $0.6 \pm 0.1$ & $0.6 \pm 0.1$ & $0.6 \pm 0.02$ \\
$\mathrm{CD}^{+} 5^{+}, \mathrm{Mac}^{+}, \mathrm{Gr}^{+}$ & $37.6 \pm 2.3$ & $52.9 \pm 4.5^{*}$ & $41.2 \pm 1.7$ \\
$\mathrm{CD} 45^{+}, \mathrm{Mac}^{+}$ & $39.9 \pm 0.6$ & $60.0 \pm 6.0^{*}$ & $46.9 \pm 0.7 \dagger$ \\
$\mathrm{CD}^{+} 5^{+}, \mathrm{Gr}^{+}$ & $37.2 \pm 1.9$ & $52.3 \pm 5.4^{*}$ & $45.6 \pm 1.2 \ddagger$ \\
$\mathrm{CD} 45^{+}, \mathrm{CD} 4^{+}, \mathrm{CD} 8^{+}$ & $0.1 \pm 0.03$ & $0.2 \pm 0.03$ & $0.30 \pm 0.03$ \\
$\mathrm{CD} 45^{+}, \mathrm{CD} 19^{+}, \mathrm{B} 220^{+}$ & $15.7 \pm 1.2$ & $6.2 \pm 0.8^{*}$ & $11.5 \pm 0.5$ \\
$\mathrm{CD} 45^{-}, \mathrm{CD} 31^{+}$ & $0.1 \pm 0.04$ & $0.2 \pm 0.1$ & $0.3 \pm 0.1$ \\
$\mathrm{CD} 45^{-}, \mathrm{CD} 34^{+}$ & nd & nd & nd \\
$\mathrm{Sca}-1^{+}, \mathrm{CD} 45^{-}$ & $0.3 \pm 0.1$ & $0.3 \pm 0.1$ & $0.3 \pm 0.1$ \\
$\mathrm{Sca}-1^{+}, \mathrm{CD} 45^{+}$ & $4.5 \pm 0.9$ & $3.6 \pm 1.0$ & $5.2 \pm 1.6$ \\
\hline
\end{tabular}

Data are expressed as mean \pm SEM of six mice. Cells were stained and analyzed using FACS analysis and shown as percentage from total population of sorted BM. nd, not detectable.

$* p<0.001$ compared to WT cells.

$\dagger p<0.05$ compared to WT cells.

$\ddagger p<0.01$ compared to WT cells.

cells predominantly repair ischemic tubular injury in the adult mammalian kidney $(25,36)$. As a consequence of tissue injury, inflammation occurs with involvement of leukocytes, adhesion molecules, and endothelial injury. The MAC-1 staining corroborates the inflammatory process, which is increased when BM cells lack P-gp or BCRP. Secondly, monocytes migrate to the site of tissue injury and differentiate into mature macrophages. These cells may not only propagate renal injury, but may also be important in inflammation resolution (42). Upon activation, macrophages release chemokines and proinflammatory cytokines that regulate local tissue remodeling by modulating the extracellular matrix components and the immune response. Macrophages also remove dying cells and this uptake of apoptotic cells inhibits the immune response. Indeed, positive effects of macrophages in renal remodeling after injury have been documented $(7,28,48)$, although their role is also under debate, because populations of macrophages are rarely seen within the renal tubules and phagocytosis of apoptotic and necrotic cells may occur by the recently identified phosphatidylserine receptor, kidney injury molecule-1 (KIM-1) (26). Preliminary data suggest that the early inflammatory response may be reduced in knockout BM transplantations (not shown). Future experiments will have to delineate the precise role of P-gp- or BCRPdeficiency on the immunological onset and response after renal ischemic injury, also in later stages of ischemia-reperfusion injury.

Intriguingly, the limited ability of BM cells to infiltrate into renal tissue increased to $20 \%$ and $30 \%$ when cells lack P-gp or BCRP, respectively. Renal function tests confirmed protection, indicating that P-gp and BCRP are potential targets for cell-based therapies in regenerative medicine. As incomplete recovery of the kidney after AKI may lead to progressive loss of renal function over time, novel, effective, treatment for AKI remains a challenge. A selective knock-down of the functional expression of P-gp or BCRP in BM cells by inhibitors or by small interfering RNAs may be a novel pharmacological approach in stem cell-based therapies. Systemic inhibition of either efflux pumps after AKI is probably less successful due to the resulting accumulation of xenobiotics and metabolic waste products.

In conclusion, we found that P-gp or BCRP deficiency in $\mathrm{BM}$ resulted in accelerated functional and morphological renal response early after ischemia-reperfusion injury, but the later stages of injury repair have to be studied to fully understand the protective mechanism in P-gp or BCRP deficiency. Furthermore, we demonstrate that BM from P-gp-or BCRP-deficient mice contains significantly more monocytes and granulocytes as well as early outgrowth endothelial progenitor cells, potentially fueling renal protection.

ACKNOWLEDGMENTS: This study was supported by the Dutch Kidney Foundation (M. Huls and R. Masereeuw; grant: C02.2012). A. Luttun was supported by an FWO postdoctoral fellowship and a KULeuven Center of Excellence Grant (EF/ 05/013). We are grateful to Ruud R. G. Bueters for his help with the transplantation experiments and Noël B. N. Knops for his help in histological analysis. P-gp-deficient $\left(\mathrm{mdr} 1 \mathrm{a} / 1 \mathrm{~b}^{-1-}\right)$ and BCRP-deficient $\left(\mathrm{bcrp}^{-1}\right)$ mice were kindly provided by the group of Dr. A. H. Schinkel (Netherlands Cancer Institute).

\section{REFERENCES}

1. Ahmed, F.; Arseni, N.; Glimm, H.; Hiddemann, W.; Buske, C.; Feuring-Buske, M. Constitutive expression of the $\mathrm{ABC}$ transporter ABCG2 enhances the growth potential of early human hematopoietic progenitors. Stem Cells 26:810-818; 2008.

2. Al Awqati, Q.; Oliver, J. A. Stem cells in the kidney. Kidney Int. 61:387-395; 2002.

3. Alvarez-Dolado, M.; Pardal, R.; Garcia-Verdugo, J. M.; Fike, J. R.; Lee, H. O.; Pfeffer, K.; Lois, C.; Morrison, S. J.; Alvarez-Buylla, A. Fusion of bone-marrow-derived cells with Purkinje neurons, cardiomyocytes and hepatocytes. Nature 425:968-973; 2003.

4. Broekema, M.; Harmsen, M. C.; van Luyn, M. J.; Koerts, J. A.; Petersen, A. H.; van Kooten, T. G.; van Goor, H.; Navis, G.; Popa, E. R. Bone marrow-derived myofibroblasts contribute to the renal interstitial myofibroblast population and produce procollagen I after ischemia/reperfusion in rats. J. Am. Soc. Nephrol. 18:165-175; 2007.

5. Bunting, K. D. ABC transporters as phenotypic markers and functional regulators of stem cells. Stem Cells 20:1120; 2002.

6. Bunting, K. D.; Zhou, S.; Lu, T.; Sorrentino, B. P. Enforced P-glycoprotein pump function in murine bone marrow cells results in expansion of side population stem cells 
in vitro and repopulating cells in vivo. Blood 96:902-909; 2000.

7. Day, Y. J.; Huang, L.; Ye, H.; Linden, J.; Okusa, M. D. Renal ischemia-reperfusion injury and adenosine $2 \mathrm{~A}$ receptor-mediated tissue protection: Role of macrophages. Am. J. Physiol. Renal Physiol. 288:F722-F731; 2005.

8. Dazert, P.; Suofu, Y.; Grube, M.; Popa-Wagner, A.; Kroemer, H. K.; Jedlitschky, G.; Kessler, C. Differential regulation of transport proteins in the periinfarct region following reversible middle cerebral artery occlusion in rats. Neuroscience 142:1071-1079; 2006.

9. de Bruijn, D. R.; Kater-Baats, E.; Eleveld, M.; Merkx, G.; Geurts Van, K. A. Mapping and characterization of the mouse and human SS18 genes, two human SS18-like genes and a mouse Ss18 pseudogene. Cytogenet. Cell Genet. 92:310-319; 2001.

10. Duffield, J. S.; Bonventre, J. V. Kidney tubular epithelium is restored without replacement with bone marrow-derived cells during repair after ischemic injury. Kidney Int. 68: 1956-1961; 2005.

11. Duffield, J. S.; Park, K. M.; Hsiao, L. L.; Kelley, V. R.; Scadden, D. T.; Ichimura, T.; Bonventre, J. V. Restoration of tubular epithelial cells during repair of the postischemic kidney occurs independently of bone marrow-derived stem cells. J. Clin. Invest. 115:1743-1755; 2005.

12. Dunn, S. R.; Qi, Z.; Bottinger, E. P.; Breyer, M. D.; Sharma, K. Utility of endogenous creatinine clearance as a measure of renal function in mice. Kidney Int. 65:19591967; 2004.

13. Fan, J. M.; Ng, Y. Y.; Hill, P. A.; Nikolic-Paterson, D. J.; Mu, W.; Atkins, R. C.; Lan, H. Y. Transforming growth factor-beta regulates tubular epithelial-myofibroblast transdifferentiation in vitro. Kidney Int. 56:1455-1467; 1999.

14. Fang, T. C.; Alison, M. R.; Cook, H. T.; Jeffery, R.; Wright, N. A.; Poulsom, R. Proliferation of bone marrowderived cells contributes to regeneration after folic acidinduced acute tubular injury. J. Am. Soc. Nephrol. 16: 1723-1732; 2005.

15. Fang, T. C.; Otto, W. R.; Jeffery, R.; Hunt, T.; Alison, M. R.; Cook, H. T.; Wright, N. A.; Poulsom, R. Exogenous bone marrow cells do not rescue non-irradiated mice from acute renal tubular damage caused by $\mathrm{HgCl} 2$, despite establishment of chimaerism and cell proliferation in bone marrow and spleen. Cell Prolif. 41:592-606; 2008.

16. Grignani, F.; Kinsella, T.; Mencarelli, A.; Valtieri, M.; Riganelli, D.; Grignani, F.; Lanfrancone, L.; Peschle, C.; Nolan, G. P.; Pelicci, P. G. High-efficiency gene transfer and selection of human hematopoietic progenitor cells with a hybrid EBV/retroviral vector expressing the green fluorescence protein. Cancer Res. 58:14-19; 1998.

17. Gupta, S.; Verfaillie, C.; Chmielewski, D.; Kren, S.; Eidman, K.; Connaire, J.; Heremans, Y.; Lund, T.; Blackstad, M.; Jiang, Y.; Luttun, A.; Rosenberg, M. E. Isolation and characterization of kidney-derived stem cells. J. Am. Soc. Nephrol. 17:3028-3040; 2006.

18. Heemskerk, M. H.; Hooijberg, E.; Ruizendaal, J. J.; van der Weide, M. M.; Kueter, E.; Bakker, A. Q.; Schumacher, T. N.; Spits, H. Enrichment of an antigen-specific $\mathrm{T}$ cell response by retrovirally transduced human dendritic cells. Cell. Immunol. 195:10-17; 1999.

19. Heemskerk, S.; van Koppen, A.; van den Broek, L.; Poelen, G. J.; Wouterse, A. C.; Dijkman, H. B.; Russel, F. G.; Masereeuw, R. Nitric oxide differentially regulates renal ATP-binding cassette transporters during endotoxemia. Pflugers Arch. 454:321-334; 2007.

20. Huls, M.; Brown, C. D.; Windass, A. S.; Sayer, R.; van den Heuvel, J. J.; Heemskerk, S.; Russel, F. G.; Masereeuw, R. The breast cancer resistance protein transporter ABCG2 is expressed in the human kidney proximal tubule apical membrane. Kidney Int. 73:220-225; 2008.

21. Huls, M.; Kramers, C.; Levtchenko, E. N.; Wilmer, M. J.; Dijkman, H. B.; Kluijtmans, L. A.; van der Hoorn, J. W.; Russel, F. G.; Masereeuw, R. P-glycoprotein-deficient mice have proximal tubule dysfunction but are protected against ischemic renal injury. Kidney Int. 72:1233-1241; 2007.

22. Huls, M.; Russel, F. G.; Masereeuw, R. The role of ABC transporters in tissue defense and organ regeneration. $\mathrm{J}$. Pharmacol. Exp. Ther. 328:3-9; 2008.

23. Huls, M.; Russel, F. G.; Masereeuw, R. Insights into the role of bone marrow-derived stem cells in renal repair. Kidney Blood Press. Res. 31:104-110; 2008.

24. Huls, M.; van den Heuvel, J. J.; Dijkman, H. B.; Russel, F. G.; Masereeuw, R. ABC transporter expression profiling after ischemic reperfusion injury in mouse kidney. Kidney Int. 69:2186-2193; 2006.

25. Humphreys, B. D.; Valerius, M. T.; Kobayashi, A.; Mugford, J. W.; Soeung, S.; Duffield, J. S.; McMahon, A. P.; Bonventre, J. V. Intrinsic epithelial cells repair the kidney after injury. Cell Stem Cell 2:284-291; 2008.

26. Ichimura, T.; Asseldonk, E. J.; Humphreys, B. D.; Gunaratnam, L.; Duffield, J. S.; Bonventre, J. V. Kidney injury molecule- 1 is a phosphatidylserine receptor that confers a phagocytic phenotype on epithelial cells. J. Clin. Invest. 118:1657-1668; 2008.

27. Jang, H. R.; Rabb, H. The innate immune response in ischemic acute kidney injury. Clin. Immunol. 130:41-50; 2009.

28. Jo, S. K.; Sung, S. A.; Cho, W. Y.; Go, K. J.; Kim, H. K. Macrophages contribute to the initiation of ischaemic acute renal failure in rats. Nephrol. Dial. Transplant. 21: 1231-1239; 2006

29. Kale, S.; Karihaloo, A.; Clark, P. R.; Kashgarian, M.; Krause, D. S.; Cantley, L. G. Bone marrow stem cells contribute to repair of the ischemically injured renal tubule. J. Clin. Invest. 112:42-49; 2003.

30. Katayama, K.; Kawano, M.; Naito, I.; Ishikawa, H.; Sado, Y.; Asakawa, N.; Murata, T.; Oosugi, K.; Kiyohara, M.; Ishikawa, E.; Ito, M.; Nomura, S. Irradiation prolongs survival of Alport mice. J. Am. Soc. Nephrol. 19:1692-1700; 2008.

31. Krause, D. S. Engraftment of bone marrow-derived epithelial cells. Ann. NY Acad. Sci. 1044:117-124; 2005.

32. Krishnamurthy, P.; Ross, D. D.; Nakanishi, T.; BaileyDell, K.; Zhou, S.; Mercer, K. E.; Sarkadi, B.; Sorrentino, B. P.; Schuetz, J. D. The stem cell marker Bcrp/ABCG2 enhances hypoxic cell survival through interactions with heme. J. Biol. Chem. 279:24218-24225; 2004.

33. Leslie, E. M.; Deeley, R. G.; Cole, S. P. Multidrug resistance proteins: role of P-glycoprotein, MRP1, MRP2, and BCRP (ABCG2) in tissue defense. Toxicol. Appl. Pharmacol. 204:216-237; 2005.

34. Li, L.; Truong, P.; Igarashi, P.; Lin, F. Renal and bone marrow cells fuse after renal ischemic injury. J. Am. Soc. Nephrol. 18:3067-3077; 2007.

35. Lin, F.; Cordes, K.; Li, L.; Hood, L.; Couser, W. G.; Shankland, S. J.; Igarashi, P. Hematopoietic stem cells contribute to the regeneration of renal tubules after renal 
ischemia-reperfusion injury in mice. J. Am. Soc. Nephrol. 14:1188-1199; 2003.

36. Lin, F.; Moran, A.; Igarashi, P. Intrarenal cells, not bone marrow-derived cells, are the major source for regeneration in postischemic kidney. J. Clin. Invest. 115:17561764; 2005.

37. McTaggart, S. J.; Atkinson, K. Mesenchymal stem cells: Immunobiology and therapeutic potential in kidney disease. Nephrology (Carlton) 12:44-52; 2007.

38. Morigi, M.; Imberti, B.; Zoja, C.; Corna, D.; Tomasoni, S.; Abbate, M.; Rottoli, D.; Angioletti, S.; Benigni, A.; Perico, N.; Alison, M.; Remuzzi, G. Mesenchymal stem cells are renotropic, helping to repair the kidney and improve function in acute renal failure. J. Am. Soc. Nephrol. 15:1794-1804; 2004

39. Neta, R. Modulation of radiation damage by cytokines. Stem Cells 15(Suppl. 2):87-94; 1997.

40. Poulsom, R.; Alison, M. R.; Cook, T.; Jeffery, R.; Ryan, E.; Forbes, S. J.; Hunt, T.; Wyles, S.; Wright, N. A. Bone marrow stem cells contribute to healing of the kidney. J. Am. Soc. Nephrol. 14(Suppl. 1):S48-S54; 2003.

41. Poulsom, R.; Forbes, S. J.; Hodivala-Dilke, K.; Ryan, E.; Wyles, S.; Navaratnarasah, S.; Jeffery, R.; Hunt, T.; Alison, M.; Cook, T.; Pusey, C.; Wright, N. A. Bone marrow contributes to renal parenchymal turnover and regeneration. J. Pathol. 195:229-235; 2001.

42. Ricardo, S. D.; van, G. H.; Eddy, A. A. Macrophage diversity in renal injury and repair. J. Clin. Invest. 118: 3522-3530; 2008

43. Ros, J. E.; Libbrecht, L.; Geuken, M.; Jansen, P. L.; Roskams, T. A. High expression of MDR1, MRP1, and MRP3 in the hepatic progenitor cell compartment and hepatocytes in severe human liver disease. J. Pathol. 200: 553-560; 2003.

44. Tabata, M.; Nishimoto, J.; Kusano, T. Spectrophotometric determination of lithium ion using a water-soluble octabromoporphyrin in aqueous solution. Talanta 46:703-709; 1998.

45. Thevenod, F.; Friedmann, J. M.; Katsen, A. D.; Hauser,
I. A. Up-regulation of multidrug resistance P-glycoprotein via nuclear factor-kappaB activation protects kidney proximal tubule cells from cadmium- and reactive oxygen species-induced apoptosis. J. Biol. Chem. 275:1887-1896; 2000.

46. Thiebaut, F.; Tsuruo, T.; Hamada, H.; Gottesman, M. M.; Pastan, I.; Willingham, M. C. Cellular localization of the multidrug-resistance gene product P-glycoprotein in normal human tissues. Proc. Natl. Acad. Sci. USA 84:7735$7738 ; 1987$.

47. Vassilopoulos, G.; Wang, P. R.; Russell, D. W. Transplanted bone marrow regenerates liver by cell fusion. Nature 422:901-904; 2003.

48. Vinuesa, E.; Hotter, G.; Jung, M.; Herrero-Fresneda, I.; Torras, J.; Sola, A. Macrophage involvement in the kidney repair phase after ischaemia/reperfusion injury. J. Pathol. 214:104-113; 2008.

49. Wang, X.; Willenbring, H.; Akkari, Y.; Torimaru, Y.; Foster, M.; Al Dhalimy, M.; Lagasse, E.; Finegold, M.; Olson, S.; Grompe, M. Cell fusion is the principal source of bone-marrow-derived hepatocytes. Nature 422:897901; 2003.

50. Yoder, M. C.; Mead, L. E.; Prater, D.; Krier, T. R.; Mroueh, K. N.; Li, F.; Krasich, R.; Temm, C. J.; Prchal, J. T.; Ingram, D. A. Redefining endothelial progenitor cells via clonal analysis and hematopoietic stem/progenitor cell principals. Blood 109:1801-1809; 2007.

51. Zhou, S.; Morris, J. J.; Barnes, Y.; Lan, L.; Schuetz, J. D.; Sorrentino, B. P. Bcrp1 gene expression is required for normal numbers of side population stem cells in mice, and confers relative protection to mitoxantrone in hematopoietic cells in vivo. Proc. Natl. Acad. Sci. USA 99:1233912344; 2002

52. Zhou, S.; Schuetz, J. D.; Bunting, K. D.; Colapietro, A. M.; Sampath, J.; Morris, J. J.; Lagutina, I.; Grosveld, G. C.; Osawa, M.; Nakauchi, H.; Sorrentino, B. P. The $\mathrm{ABC}$ transporter Bcrp1/ABCG2 is expressed in a wide variety of stem cells and is a molecular determinant of the side-population phenotype. Nat. Med. 7:1028-1034; 2001. 